\section{A Simple PCR Method for Screening CDNA Libraries}

\section{Dominique Alfandari and Thierry Darribère}

Université Pierre et Marie Curie, Unité Associée, Centre National de la Recherche Scientifique (CNRS) 1135, Laboratoire de Biologie Moléculaire et Cellulaire du Développement, Groupe de Biologie Expérimentale, 75005 Paris, France
The development of DNA amplification by PCR homology methods has led to the isolation of a number of DNA fragments from many cell lines and species. The partial DNAs obtained can then be used to quantify and localize the corresponding mRNA but are too small for fusion protein production and most functional studies. Furthermore, Thermus aquaticus (Taq) DNA polymerase is known to introduce mutations, both insertional and substitutional, to the PCR product. $^{(1-3)}$ For these reasons, it is necessary to isolate clones encoding the protein of interest from libraries. Usually, hybridization of a radiolabeled probe to phage plaques, immobilized on a filter, is employed. Unfortunately, this technique is often ineffective with small DNA probes. Recently, a PCR-based method, efficient for screening genomic DNA libraries, has been described. ${ }^{(4)}$ The method is based on PCR screening using two oligonucleotide primers specific for the desired gene. A third oligonucleotide labeled with ${ }^{32} \mathrm{P}$ is used to confirm the specificity of the PCR products by hybridization. Here, we describe a simple and efficient technique that uses no radioactivity and requires only two specific oligodeoxynucleotide primers. By utilizing the speed, specificity, and sensitivity of PCR we are able to screen several libraries simultaneously. Once the best possible library is identified, pure cDNA encoding the clone of interest can be in hand in 6 days. To illustrate this method, we describe the isolation of DNAs encoding the amphibian integrin $\alpha_{\mathrm{v}}$-subunit.

\section{MATERIALS AND METHODS}

\section{Preparation of Phagemid and Plasmid Libraries}

Four amphibian (Pleurodeles waltl) cDNA libraries were analyzed. They were constructed in the $\lambda$ Zap II vector (Stratagene, La Jolla, CA) from ovaries (gift of Drs. Bellini and Lacroix, Unité Associée CNRS 1135, Paris, France) and dorsal and ventral blastomeres of eight-cell-stage embryos (gift of Dr. Cayrol, Unité Mixte de Recherche, CNRS 9925, Toulouse, France), and tailbud-stage embryos. ${ }^{(5)}$ Phagemid libraries were generated by in vivo excision. ${ }^{(6)}$ Briefly phages of the libraries $\left(10^{7} \mathrm{PFU}\right)$ were mixed with $10^{7}$ helper phages (R408) and incubated with $1 \mathrm{ml}$ of freshly prepared Escherichia coli strain XL1-Blue $\left(10^{8}\right.$ cells, Stratagene) for $30 \mathrm{~min}$ at $37^{\circ} \mathrm{C}$. The mixture was then diluted in $10 \mathrm{ml}$ of super broth (SB) media and grown for $3 \mathrm{hr}$ at $37^{\circ} \mathrm{C}$. Phagemids were released by heating at $70^{\circ} \mathrm{C}$ for $20 \mathrm{~min}$. Bacterial debris was eliminated by centrifugation at $2500 \mathrm{~g}$ for $10 \mathrm{~min}$. Phagemid libraries were stored at $4^{\circ} \mathrm{C}$ for further use.

Plasmid libraries were prepared by incubating $1 \mathrm{ml}$ of each phagemid library combined with $1 \mathrm{ml}$ of $E$. coli strain XL1Blue $\left(10^{8}\right.$ cells $)$ at $37^{\circ} \mathrm{C}$ for $30 \mathrm{~min}$. Infected bacteria were grown in $50 \mathrm{ml}$ of Luria broth containing $50 \mu \mathrm{g} / \mathrm{ml}$ of ampicilin (LBA) overnight at $37^{\circ} \mathrm{C}$. Plasmids were recovered using alkaline lysis, phenol chloroform extraction, and ethanol precipitations. DNA was suspended in $100 \mu \mathrm{l}$ of $10 \mathrm{~mm}$ Tris, $1 \mathrm{~mm}$ EDTA (TE) containing $10 \mu \mathrm{g} / \mathrm{ml}$ of RNase A (TER). Aliquots of these plasmid libraries were then used as templates for PCR to determine the presence of the cDNA of interest and consequently to select the phagemid library to be screened.

\section{Titration of the Desired CDNA}

To evaluate the abundance of the desired cDNA clone in the selected phagemid library, 10 -fold serial dilutions were made $\left(1-10^{5}\right)$. Each dilution of the phagemid library $(100 \mu \mathrm{l})$ was used to infect $10^{7}$ host bacteria $(100 \mu \mathrm{l})$ for $30 \mathrm{~min}$ at $37^{\circ} \mathrm{C}$. These mixtures were then diluted in LBA $(5 \mathrm{ml})$ from which $50 \mu \mathrm{l}$ was spread on LBA plates. After growth overnight, colonies were counted to determine the number of colony forming units (CFU). In parallel, plasmids were prepared from each dilution, and PCR was performed as described below. The minimal number of colonies that yielded the expected PCR product defined the frequency of the cDNA of interest in the library and therefore the working dilution of the phagemid library used for the screen.

\section{Screening Procedure}

The phagemid library at the working dilution was used to infect $E$. coli strain XL1-Blue. Bacteria were seeded in 96well plates in $300 \mu \mathrm{l}$ of LBA, which corresponds to $40 \mathrm{CFU}$. After overnight growth, $100 \mu \mathrm{l}$ of liquid culture from the 12 wells across each lane was pooled. Plasmid extractions were performed by the alkaline lysis method giving 8-lane plasmid pools (Lpps) for each plate (Fig. 
1). Then, one-tenth of each Lpp was mixed creating plate plasmid pools (Ppps). The Ppps (10 $\mu \mathrm{I})$ were used as templates for PCR. The presence of the expected PCR product identifies the plate containing the desired CDNA. PCR was performed on each Lpp from positive plates. To identify positive wells, plasmids extracted from each of the 12 wells in the positive lanes were analyzed by PCR. Bacteria from the positive well were diluted and spread on an LBA plate. Following overnight growth, single colonies were picked and seeded in a 96well plate. A second screen was then performed exactly as described before. To

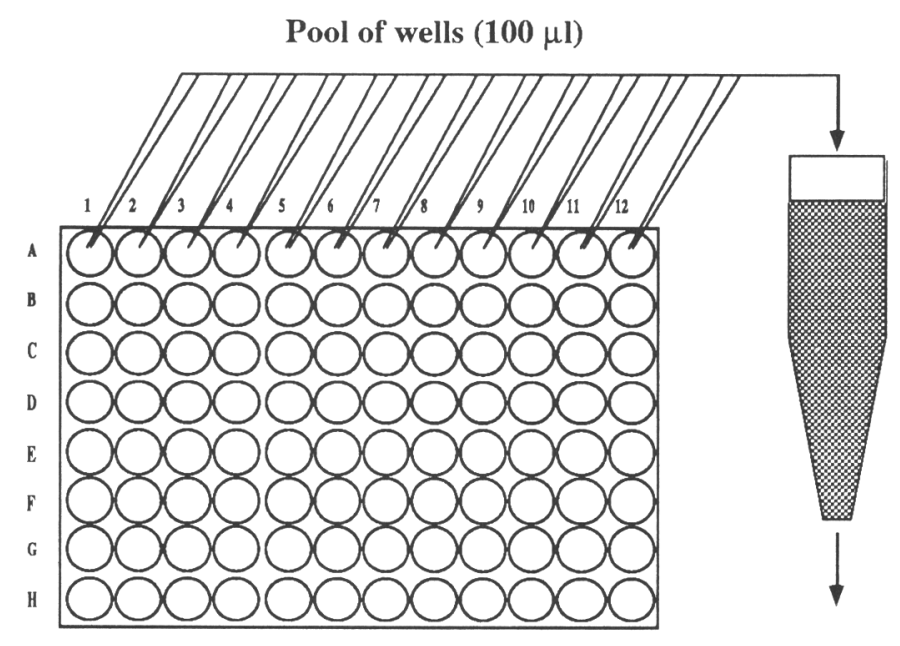

$\sqrt{1}$

Plasmid extraction of the 8 pools (Lpp)

\footnotetext{
Plate screen

1) mix 1/10th of each Lpp to give the plate plasmid pool (Ppp)

2) PCR on each Ppp

3) agarose gel electrophoresis

$\checkmark$
}
Lane screen
1) PCR on each Lpp of positive plates
2) agarose gel electrophoresis
$\downarrow$

\section{Isolation of positive clones}

FIGURE 1 Schematic diagram of the PCR screening procedure. Once the dilution of the phagemid library containing the cDNA of interest was determined, infected bacteria were diluted and seeded in 96-well plates. After overnight growth, $100 \mu \mathrm{l}$ of culture from 12 wells across each lane of each plate was pooled. The 96 wells were therefore reduced to eight pools per plate. For each pooled lane, plasmid extraction was performed (Lpp) and one-tenth of each Lpp was mixed to serve as templates for the plate screen. Once positive plates were identified, PCR screening was done for positive lanes on aliquots of the Lpp. Each well within positive lanes was then tested by PCR. Finally, individual clones from the positive well were submitted to PCR, resulting in the isolation of the CDNA of interest. Negative controls for PCR specificity were done by reactions lacking the template, and positive controls by amplifications with the cDNA obtained by homology PCR. Finally, the reaction product was tested for restriction digestion with BgllI generating one 48-bp and one 174-bp fragment. avoid contamination artifacts, bacteria from the positive well of the second screen were diluted and spread on an LBA plate. Ten isolated colonies were randomly picked and grown in 12-ml culture tubes. Plasmids were extracted and aliquots used as templates for PCR.

\section{PCR}

The $5^{\prime}$ primer $\left(5^{\prime}\right.$-TCTGTGGCTGCCACT$3^{\prime}$ and $3^{\prime}$ primer (5'-GTCAAGGTCACCAAG-3') were synthesized based on the sequence of the partial cDNA encoding $P$. walt integrin $\alpha_{\mathrm{v}}$ subunit obtained by PCR homology. ${ }^{(7)}$ PCR was performed in a reaction volume of $100 \mu \mathrm{l}$ in buffer containing $2.3 \mathrm{mM} \mathrm{MgCl}, 0.1 \mathrm{mM}$ of each dNTP, $0.2 \mu \mathrm{M}$ of each primer, and 0.5 units of Taq DNA polymerase (Appligene). The reaction was done with an initial denaturation of $5 \mathrm{~min}$ followed by 35 cycles $\left(94^{\circ} \mathrm{C} / 30 \mathrm{sec} ; 55^{\circ} \mathrm{C} / 30 \mathrm{sec} ; 72^{\circ} \mathrm{C} /\right.$ $20 \mathrm{sec}$ ) and a final extension step of 10 min at $72^{\circ} \mathrm{C}$ in a thermal cycler (Hybaid). Reaction products $(10 \mu \mathrm{l})$ were electrophoresed through a $2 \%$ agarose/TAE gel (40 mM Tris acetate, 2 mM EDTA) and visualized with ethidium bromide staining.

\section{RESULTS}

Using homology PCR targeted at integrin $\alpha$ subunits, we previously obtained 315-bp DNA fragment. Sequence analysis of this DNA using the Genetics Computer Group (GCG) software package, ${ }^{(8)}$ shows $70 \%$ identity with human integrin $\alpha_{v}$ subunit. To obtain full-length cDNAs, a library screening was performed by plaque hybridization using the PCR ${ }^{32}$ P-labeled probe. ${ }^{(9)}$ This method was ineffective in isolating the desired cDNA clone. To overcome this problem, another screening strategy was designed using sensitivity and specificity of PCR. The primer set used was based on sequence obtained from the partial cDNA encoding the homolog of the integrin $\alpha_{\mathrm{v}}$ subunit. Use of these primers results in a 222-bp amplification product that contains an internal $B g l l I$ restriction site located $174 \mathrm{bp}$ from the $5^{\prime}$ primer. To determine which library would be screened, aliquots of the four plasmid libraries were analyzed by PCR. Results indicate that the 222-bp reaction product was amplified from each library (Fig. 2A) With the same PCR conditions, the highest intensity of the 222-bp band was ob- 


\section{Technical TipsIIIII}

A

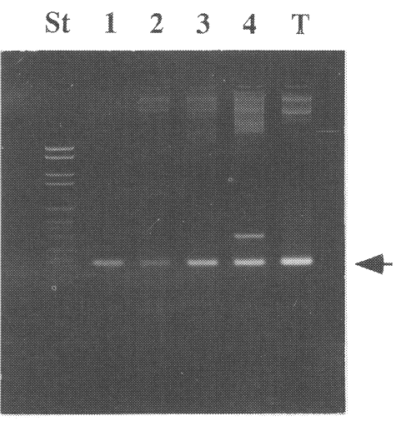

C
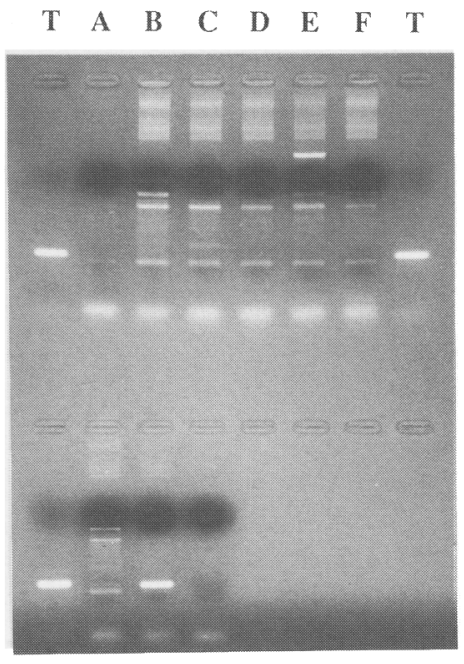

$\begin{array}{llllllllll}T & G & H & O\end{array}$

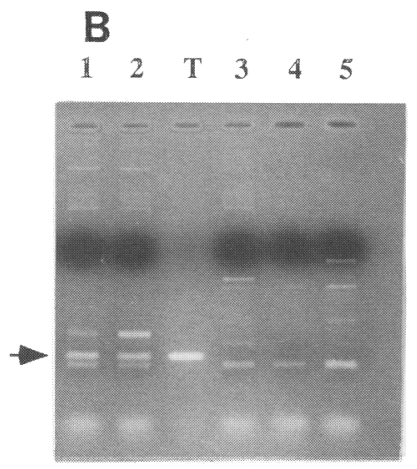

D

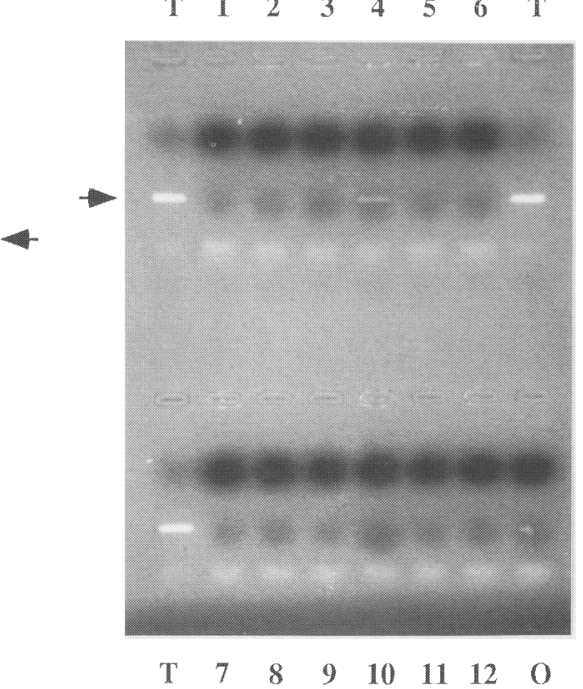

FIGURE 2 Analysis of amplification products of the first-round screening. ( $A$ ) Determination of the library to be screened. Aliquots of the PCR product from ovaries (lane 1), ventral (lane 2), and dorsal (lane 3) blastomere of eight-cell stage embryos, and tailbud stage embryo (lane 4) libraries. The 222-bp reaction product (arrow) was amplified from each plasmid library. (Lane T) Positive control; (lane ST) DNA molecular weight markers VI (Boehringer). (B) Determination of the working dilution. Serial 10-fold dilutions of the dorsal library were tested by PCR. The 222-bp amplified product was found for $10^{-1}$ (lane 1) and $10^{-2}$ (lane 2) but not for subsequent dilutions of $10^{-3}$ (lane 3 ), $10^{-4}$ (lane 4 ), $10^{-5}$ (lane 5). (C) Lane screening. Bacteria from each well of the same lane were pooled. Plasmids were extracted from these pools. Aliquots of each lane pool were used as templates for amplification reactions. Reaction products were electrophoresed through a $2 \%$ agarose gel. Amplifications with the starting clone in pBluescript (lane $T$ ) and with no template (lane $O$ ) were used, respectively, as positive and negative controls. The expected band at 222 bp (arrows) is found only in lane $H$. (D) Well screening. Plasmids extracted from each well of the positive land $H$ were used as templates for amplification. The products of the 12 reactions were electrophoresed. The amplification products of the starting clone were electrophoresed as controls (lanes $T$ ). In the last lane, a negative control was done by reaction lacking the template. The expected band (arrow) is detected in the reaction product from plasmid pool of well 4 .

served when plasmids from the dorsal blastomere and tailbud libraries were used as template. The dorsal blastomere library was chosen for further screening.

Serial 10 -fold dilutions of the dorsal blastomere phagemid library were used to infect $10^{7}$ bacteria/ $\mu$ l. Aliquots $(1 / 100$ of each dilution) were spread on LBA plates, and the rest was grown overnight. The colonies were counted for each dilution to determine the number of CFUs.
In parallel, plasmids were extracted from overnight cultures, and used as templates for PCR. Reaction products were analyzed by gel electrophoresis. Results show that the 222-bp band is still present in the $10^{-2}$-fold dilution (Fig. 2B). On LBA plates, the bacteria count indicates that this dilution corresponds to 20,000 CFU. Therefore, the cDNA of interest was present in at least 1 of every 20,000 inserts in the dorsal blastomere library.
Thus, the starting phagemid library was diluted 100 -fold and used to seed each well of five 96-well plates with 40 CFU. Following overnight culture, PCR screening was performed for plates, lanes, and wells exactly as described in Figure 1 . The Ppps from plate 2 produced the expected PCR band (not shown). PCR was then done on the 8 lanes (Lpp) of plate 2 (Fig. 2C). The amplification product of plasmids pooled from lane $\mathrm{H}$ contained the expected 222-bp band. Each well of lane $\mathrm{H}$ was then screened by PCR. Only well number 4 produced the 222-bp amplification product (Fig. 2D). To isolate positive clones, the bacterial mixture of well number 4 , which contains $\sim 40$ distinct CFU, was spread on LBA plates. Following overnight growth, isolated colonies were picked and seeded in a 96-well plate. After culture, the second-round screen was performed on plasmids pooled by lanes and then, from wells of positive lanes (Fig. 1). The amplified product of $222 \mathrm{bp}$ was detected in one well (not shown). The corresponding bacteria were spread on LBA plates. After growth, plasmids were extracted from 10 randomly selected colonies and analyzed by PCR. Three of the 10 colonies shown an amplification poduct of $222 \mathrm{bp}$. Each of these three were cleaved by BglII, confirming their identity. One of these clones was selected for further analysis. Restriction mapping, and sequencing indicates that the plasmids contain a $3.2-\mathrm{kbp}$ insert that encodes the amphibian integrin $\alpha_{\mathrm{v}}$-subunit. ${ }^{(6)}$

\section{DISCUSSION}

By PCR homology, we previously isolated a 315-bp fragment of DNA encoding the amphibian homolog of the integrin $\alpha_{v}$ subunit. To obtain full-length clones, we have screened a cDNA library by the filter hybridization technique using PCR generated ${ }^{32} \mathrm{P}$-labeled probes. ${ }^{(8)}$ A screen of $10^{6}$ phages was unsuccessful even though clones were present in the library based on the PCR homology results. To circumvent this fruitless approach, we have developed a simple and nonradioactive PCR-based method by which cDNA clones may be isolated from a $\lambda$ Zap library. To illustrate this cloning technique, we have described the isolation of a $3.2-\mathrm{kbp}$ cDNA encoding the amphibian integrin $\alpha_{\mathrm{v}}$-subunit.

The sequence of the partial $\alpha_{v}$ cDNA isolated by PCR homology was used to 
generate specific oligodeoxynucleotide primers. To have an efficient control of the specificity of the amplification reactions, they were designed to generate an amplified fragment containing a unique and easily detectable restriction site. Alternatively, if no restriction site is available, an internal oligodeoxynucleotide could be used to confirm identity of PCR products. To increase the selectivity, we have found that it is important to establish the optimal amplification reaction conditions before screening. These conditions are easier to determine if longer primers are used ( $20-30$ bases); however, primers as small as 15 bases have been successfully employed in our study. We have also observed that it is important to keep the number of colony forming units per well low because competition for growing in small volumes can result in the loss of the clone.

Prior to screening, we had evidence that our desired cDNA would be abundant in libraries constructed from RNA isolated from early stage embryos. Because we had several libraries available, we wished to select the optimal one. To do this, a preliminary PCR screen was performed. Templates from the dorsal blastomere library resulted in the most intense amplification product and was therefore selected for further screening. In many instances, this additional step could be omitted giving a more rapid cloning procedure.
When the reaction conditions are identified, the amplification reactions are completed within $2 \mathrm{hr}$, depending on the length of the fragment to be amplified. Therefore, the entire screening procedure can be completed within 1 week. A step-by-step screening plan is suggested in Table 1.

The method we have described provides an alternative to plaque hybridization for screening cDNA libraries. In our hands, the PCR technique was more effective than the filter hybridization technique with PCR-generated ${ }^{32} \mathrm{P}$-labeled probes. With the plaque hybridization method we unsuccessfully screened $10^{6}$ colonies. Conversely, $2 \times 10^{4}$ colonies of the same library were screened to isolate the desired cDNA with the described PCR procedure.

This protocol is also inexpensive. For each amplification reaction, we have used the Taq DNA polymerase at low concentrations, which brings the price of each reaction lower than a restriction digestion. The complete screening procedure to isolate the clone of inquiry had used $<200$ units of the enzyme. Furthermore, hybridization membranes, X-ray films and ${ }^{32}$ P-labeled nucleotides are unnecessary.

While this paper was in preparation, a similar method was described. ${ }^{(10)}$ The method used PCR screening directly on phages. We have found that amplification on unpurified phage DNA was not

TABLE 1 Proposed Step-by-step Procedure for Screening

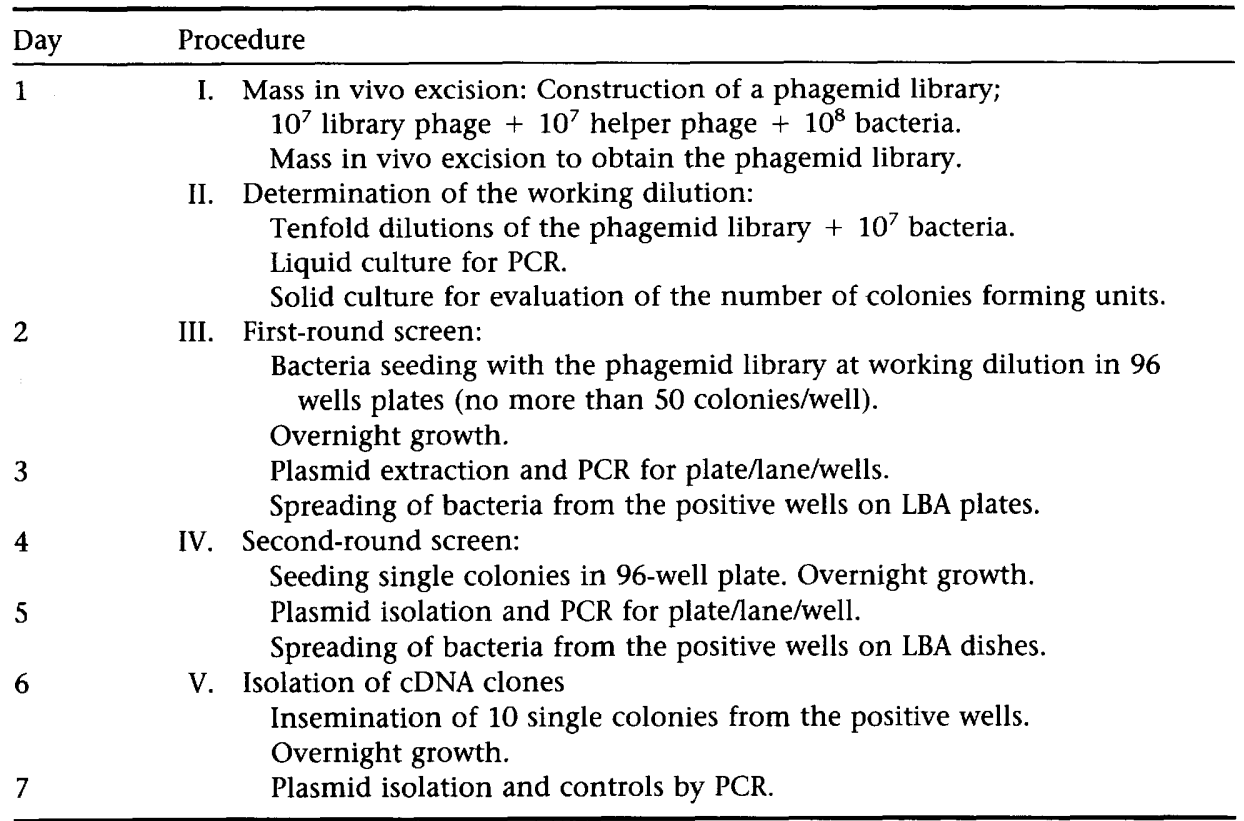

as efficient as that using purified plasmids. However, both techniques are nonradioactive and emphasize the need for various rapid and efficient screening procedures.

\section{ACKNOWLEDGMENTS}

We thank Pr. J.C. Boucaut for constant support and encouragement. We are also grateful to C. Whittaker, Dr. D. DeSimone for helpful discussions and advice and to Drs. D. Dunon, J.F. Riou, and D.L. Shi for critical reading of the manuscript. This work was supported by grants from CNRS (URA 1135) and Institut Universitaire de France.

\section{REFERENCES}

1. Clark, J.M. 1988. Novel non-templated nucleotide addition reactions catalyzed by procaryotic and eucaryotic DNA polymerases. Nucleic Acids Res. 16: 9677-9686.

2. Saiki, R.K., D.H. Gelfand, S. Stoffel, S.J. Scharf, R. Higuchi, G.T. Horn, K.B. Mullis, and H.A. Erlich. 1988. Primer-directed enzymatic amplification of DNA with a thermostable DNA polyerase. Science 239: 487-491.

3. Eckert, K.A. and T.A. Kunkel. 1990. High fidelity DNA synthesis by the Thermus aquaticus DNA polymerase. Nucleic Acids Res. 18: 3739-3752.

4. Israel, D.I. 1993. A PCR-based method for high stringency screening of DNA libraries. Nucleic Acids Res. 21: 2627-2631.

5. Shi, D.L., J.J. Feige, J.F. Riou, D.W. DeSimone, and J.C. Boucaut. 1992. Differential expression and regulation of two distinct fibroblast growth factor receptors during early development of the urodele amphibian Pleurodeles waltl. Development 116: 261-273.

6. Alfandari, D., C.A. Whittaker, D.W. DeSimone, and $\mathrm{T}$. Darribère. (in prep.)

7. Maniatis, T., E.F. Fritsch, and J. Sambrook. 1989. Molecular cloning: A laboratory manual, 2nd ed. Cold Spring Harbor Laboratory Press, Cold Spring Harbor, New York.

8. Devereux, J., P. Haeberli, and O. Smithies. 1984. A comprehensive set of sequence analysis programs for the VAX. Nucleic Acids Res. 12: 387-395.

9. Schowalter, D.B. and S.S. Sommer. 1989. The generation of radioalabeled DNA and RNA probes with polymerase chain reaction. Annal. Biochem. 177: 90-94.

10. Amaravadi, L. and M.W. King. 1994. A rapid and efficient, nonradioactive method for screening recombinant DNA libraries. BioTechniques 16: 98-104.

Revised May 13, 1994; accepted in revised form June 22, 1994. 


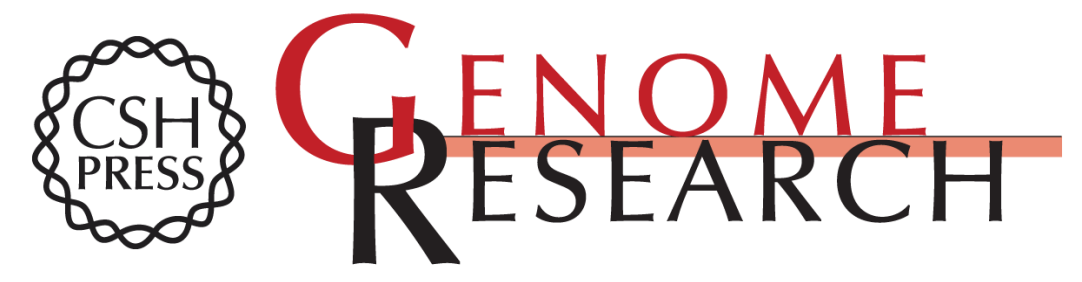

\section{A simple PCR method for screening cDNA libraries.}

D Alfandari and T Darribère

Genome Res. 1994 4: 46-49

References This article cites 8 articles, 2 of which can be accessed free at: http://genome.cshlp.org/content/4/1/46.full.html\#ref-list-1

\section{License}

Email Alerting Receive free email alerts when new articles cite this article - sign up in the box at the Service top right corner of the article or click here.

\section{Affordable, Accurate Sequencing.}

To subscribe to Genome Research go to: https://genome.cshlp.org/subscriptions 